Goldschmidt 2021 Abstract

https://doi.org/10.7185/gold2021.7516 serpentinized mass during chloritization are characterized by a high bring of $\mathrm{CO}_{2}$ and $\mathrm{CaO}$ and a low enrichment of alumina.

\section{Geochemical alterations and precious metals (Au-Ag) in Taghouni Prospect in the Bou Azzer mining district (Central Anti-Atlas, Morocco)}

\author{
HAMID DANI ${ }^{1}$, MUSTAPHA EL GHORFI ${ }^{2,3}$, ABDELHAFID \\ EL FLES EL ALAOUI ${ }^{4}$ AND LHOU MAACHA ${ }^{5}$ \\ ${ }^{1}$ Laboratoire de Géosciences, Géo-environnement et Génie civil \\ (L3G), Département de Geologie, Faculté des Sciences et \\ Techniques, Université Cadi Ayyad \\ ${ }^{2}$ Dept. of Earth Sciences, University Cadi Ayyad, Faculty of \\ Sciences - Technics and Engineering (FSTE) \\ ${ }^{3}$ Geology and Sustainable Mining, Mohammed VI Polytechnic \\ University \\ ${ }^{4}$ Laboratoire de Géosciences, Géo-environnement et Génie civil \\ (L3G), Département de Géologie, Faculté des Sciences et \\ Techniques, Université Cadi Ayyad \\ ${ }^{5}$ MANAGEM, Twin Center, BP 5199, 20100 Casablanca \\ Presenting Author: danihamid266@gmail.com
}

The Taghouni prospect is a part of the Bou-Azzer mining district, that is known with its mineralization of (Co-Ni-As-Au$\mathrm{Ag}$ ), which is located in the the central Anti Atlas of Morocco. The Taghouni prospect is characterized by a cobalt-bearing mineralization which occurs in fractures that intersect a quartz diorite body adjacent to the serpentinites part of the Bou Azzer ophiolite complex. This mineralization is under a direct control of two populations of fractures $\left(N 70^{\circ}\right.$ and $\left.N 120^{\circ}\right)$ with a sinistral distensive kinematic. In addition to the cobalt mineralization, precious metals $(\mathrm{Au}-\mathrm{Ag})$ indices have been identified in this area associated to the (Co-Ni-Cr-As) mineralization.

Most of the gold-bearing mineralization occur as small free grains or stringers in microcrystalline quartz veins, as well as in quartz-filled vuggy structures, these geodes are interpreted as the result of the recrystallization of microcrystalline quartz. The gold-bearing paragenesis is probably related to a jerky series of silicifications responsible, on the one hand, for the appearance of microcrystalline quartz veinlets and, on the other hand, for the remobilization of the silica towards the geodes.

The petrographic examination of the quartz diorites has shown that they are affected by several alterations, in a system of nested zones around the Taghouni shear zones. The Mineralogical modifications consist of epidote leaching and the neoformation of sericite, magnetite, pyrite, albite and leucoxene. These alterations do not apparently related to the mineralization. In the other hand, we note that silicification, carbonation and chlorotization are closely related to the mineralization. Those are expressed as quartz and carbonate veinlets (calcite, dolomite), and a chloritites breccia.

The chemical variations result from an interaction between the quartz diorite and the solution, from which the rock recognized a total subtraction of $\mathrm{CaO}$, an addition of $\mathrm{Na}_{2} \mathrm{O}$ and $\mathrm{K}_{2} \mathrm{O}$, and a possible addition of $\mathrm{FeO}$ and $\mathrm{MgO}$, however, the $\mathrm{TiO}_{2}$ remains unchanged. The global reaction, which combines these modifications, corresponds to the attack of the quartz diorite by an acid solution. The metasomatic reactions with the 